\title{
The A rabidopsis HY 5 gene encodes a bZIP protein that regulates stimulus-induced development of root and hypocotyl
}

\author{
Tokitaka Oyama, ${ }^{1}$ Yoshiro Shimura, ${ }^{2}$ and Kiyotaka Okada,3 \\ ${ }^{1}$ Department of Botany, Graduate School of Science, Kyoto University, Kyoto 606-01, Japan; ${ }^{2}$ Biomolecular Engineering \\ Research Institute, Furuedai, Suita, Osaka 565, Japan
}

\begin{abstract}
Plant developmental processes are controlled by both endogenous programs and environmental stimuli. As a photomorphogenetic mutant, hy5 of A rabidopsis has been isolated and characterized. Our detailed characterization has revealed that the mutant is deficient in a variety of stimulus responses, including gravitropic response and waving growth of roots, as well as light-dependent hypocotyl el ongation. In the roots and hypocotyl, the hy5 mutation also affects greening and specific cell proliferation such as lateral root formation and secondary thickening. Those phenotypes indicate that the H Y 5 gene is responsible for the regulation of fundamental developmental processes of the plant cell: cell elongation, cell proliferation, and chloroplast development. Molecular cloning of the HY 5 gene using a T-DNA-tagged mutant has revealed that the gene encodes a protein with a bZIP motif, one of the motifs found in transcriptional regulators. Nuclear localization of the HY5 protein strongly suggests that the HY 5 gene modulates the signal transduction pathways under the HY5-related devel opment by controlling expression of genes downstream of these pathways.
\end{abstract}

[Key Words: Arabidopsis; HY5; stimulus-responses; photomorphogenesis; root development; bZIP protein]

Received June 30, 1997; revised version accepted September 12, 1997.

Plant devel opment is influenced by many environmental factors. Light, gravity, temperature, touching, and chemical compounds are perceived as stimuli by plants and affect the choice of development programs. Light is one of the most important stimuli to plant devel opment. Seedlings grown in the light or in darkness take quite different morphological strategies, called photomorphogenesis or skotomorphogenesis, respectively. Lightgrown seedlings show a short hypocotyl with green and expanded cotyledons. On the other hand, dark-grown, or etiolated seedlings, show a long hypocotyl with yellow and unopened cotyledons. The light-regulated development in young seedl ings has been dissected through molecular genetic approaches in Arabidopsis thaliana (for review, see Chory 1993; Deng 1994; M cN ellis and Deng 1995). A class of hy mutations designated for their long hypocotyl phenotype in the light has defects in lightcapturing molecules; the hy1, hy2, phyB (formerly designated hy3), and hy6 mutants have been shown to be deficient in phytochromes, whereas the hy 4 mutant is deficient in a blue light receptor (Koornneef et al. 1980; Chory et al. 1989a; Parks and Quail 1991; Ahmad and
Cashmore 1993; Reed et al. 1993). Of the six hy loci, the molecular role of the HY5 gene has not been clarified. Another class of mutations, including deetiol ated (det) and constitutively photomorphogenic (cop), shows morphology of dark-grown seedlings similar to that of the light-grown seedlings of the wild-type (for review, see Chory 1993; Deng 1994; McN ellis and Deng 1995). It is suggested that the DET and the COP gene products work as repressors of photomorphogenesis when grown in darkness, and a number of DET / COP class gene products including DET 1 and COP1 are thought to modulate the signal transduction pathways that originate from photoreceptors related to HY1, HY2, PHYB, HY6, and HY4 genes. The DET 1 and the COP1 genes have been shown to encode nuclear proteins that are thought to modulate the pathways by repressing light-regulated gene expression (Chory et al. 1989b; Deng et al. 1992; Pepper et al. 1994; von Arnim and Deng 1994). The HY5 gene product also has been regarded as a mediator in the light-dependent signal transduction pathways (Chory 1992; Ang and Deng 1994).

In our study of mechanisms of root morphogenesis and stimulus responses in the root as a model system of plant devel opment, we have examined a series of hy5 mutants and found that these mutants show common interesting 
phenotypes in the root morphology under the control of environmental stimuli and endogenous programs of development (Okada and Shimura 1994). Recently, extensive genetic studies on root systems of A rabidopsis have been started, and a number of mutants deficient in stimulus response or development of roots have been isolated and characterized (for review, see Okada and Shimura 1992a; A eschbacher et al. 1994; Dolan and Roberts 1995). M utants with aberrant root gravitropism, including aux1, dwf, axr1, axr2, and axr4 show resistance to auxin, indicating that those genes work both in the signaling pathway of gravitropism and in auxin-related developmental systems (Wilkins 1966; Juniper 1976; Fel dman 1984; Hobbie and Estelle 1995). The AXR1 gene encodes a protein rel ated to ubiquitin-activating enzyme E1, and it has been implied that the ubiquitin pathway may play a role in plant hormone action (Leyser et al. 1993). The AUX 1 gene encodes a permease-like protein possibly working in auxin uptake (Bennett et al. 1996). Studies on the developmental steps in root meristem formation have al so been progressing, and a number of mutants have been reported to be deficient in speci fic layers of radial organization, or in cell shape of the root (for review, see Aeschbacher et al. 1994; Dolan and Roberts 1995). The SCARECROW gene, which regulates an asymmetric cell division of the cortex/endodermal initial, encodes a protein with a basic leucine zipper (bZIP)like domain, and has been indicated as a transcription factor (Di Laurenzio et al. 1996). Although some genes have been cloned, their molecular mechanisms are largely unknown.

Recently, anatomical and genetic studies on lateral roots of A rabidopsis have been started. The lateral roots originate in pericycle cells of the main root. Although the morphology of lateral roots looks similar to that of the main root, the origin and the formation pattern are different from each other (Dol an et al. 1993; M alamy and Benfey 1997). Auxin can induce lateral root initiation (Laskowski et al . 1995). Several mutants, includingaux1, axr1, axr4 (Hobbie and Estelle 1995), alf1, alf3, alf4 (Celenza et al. 1995), and surl (Boerjan et al. 1995), show abnormality both in lateral root formation and in auxinrelated responses.

In this paper we report detailed characterization of the phenotypes of the hy5 mutants, including stimulus responses, lateral root formation, secondary thickening in roots, and photomorphogenesis of young seedlings. We also report the cloning and molecular characterization of the HY5 gene. By integrating the genetic, morphol ogical, and molecular data, we find that the HY5 gene works in the nucleus as a key modulator of signal transduction pathways mediating a wide vari ety of stimulus responses and developmental processes in the root and hypocotyl.

\section{Results}

Phenotypes of hy5 mutants

As shown in Figure 1, A-D, three different alleles of hy5 mutants show similar structural and developmental phe- notypes in the hypocotyl and roots of plants on agar plates set in the vertical position. Structural abnormalities were not found in other organs, including leaves, stems, and flowers.

The hy5 mutation enhances cell el ongation in hypocotyl and root hairs When germinated in the light, hypocotyls in hy5 mutants are longer than those in the wild type (Table 1). The longitudinal length of epidermal cells was 1.9 times that of the wild type, indicating that the longer hypocotyl of the mutants largely depends on the higher degree of cell el ongation. It is well known that the length of the hypocotyl is increased when seeds are germinated in darkness, namely, elongation of hypocotyl cells is repressed by light. Interestingly, the hypocotyl length of the mutant was identical to that of the wild type when both plants were grown in darkness (Table 1). This suggests that the hy5 mutation abolishes the lightdependent repression of cell elongation and does not simply promote cell elongation independent of light stimulus.

Excessive cell elongation was also observed in root hairs of the hy 5 mutant. As shown in Table 2 and Figure $1, E$ and $F$, the root hair length of the mutant was 1.5 times greater than that of the wild type, whereas the length of root-hair-bearing epidermal cells was less affected by the hy5 mutation.

The hy5 mutation alters the gravitropic response and touching response in roots One of the clear characters of hy5 mutants grown on agar plates was the widely spread lateral roots (Fig. 1A-D, arrowheads). Compared with that of wild-type plants, the di rection of lateral root growth was nearly horizontal rather than downward, indicating alteration of the gravitropic response. To examine the degree of the gravitropism, we measured the angles between the lateral roots and the orientation of gravity. The angles of lateral roots of the mutant were larger than those of the wild type (Table 3). In addition, secondary lateral roots grew and changed their direction of elongation to the horizontal (Fig. $1 \mathrm{H}$ ). These results suggest that lateral roots of the hy5 mutant lack normal gravitropism and may obtain a new type, called diageotropism (Darwin 1882). The main root of the hy5 mutant also showed a reduced gravitropic response. As shown in Figure $1 \mathrm{~A}$, the main root of the wild type elongated with a slight slant to the viewer's left (clockwise). The angle of slant of hy5-1 was two times greater than that of the wild type (Table 3 ), indicating that the main root of the hy5 mutant shows reduced gravitropism and/or increased circumnutation (Simmons et al . 1995). However, the reduced gravitropic response of the main root of the mutant was also shown by changing the position of the agar plate, after which the main root of wild-type Arabidopsis forms a hairpin loop. hy5-1 showed a larger arc than the wild type because of a slow response to the position shift (data not shown). These results suggest that the gravitropic response of the main root is reduced in the hy5 mutant.

When seedlings of wild-type Arabidopsis are incu- 


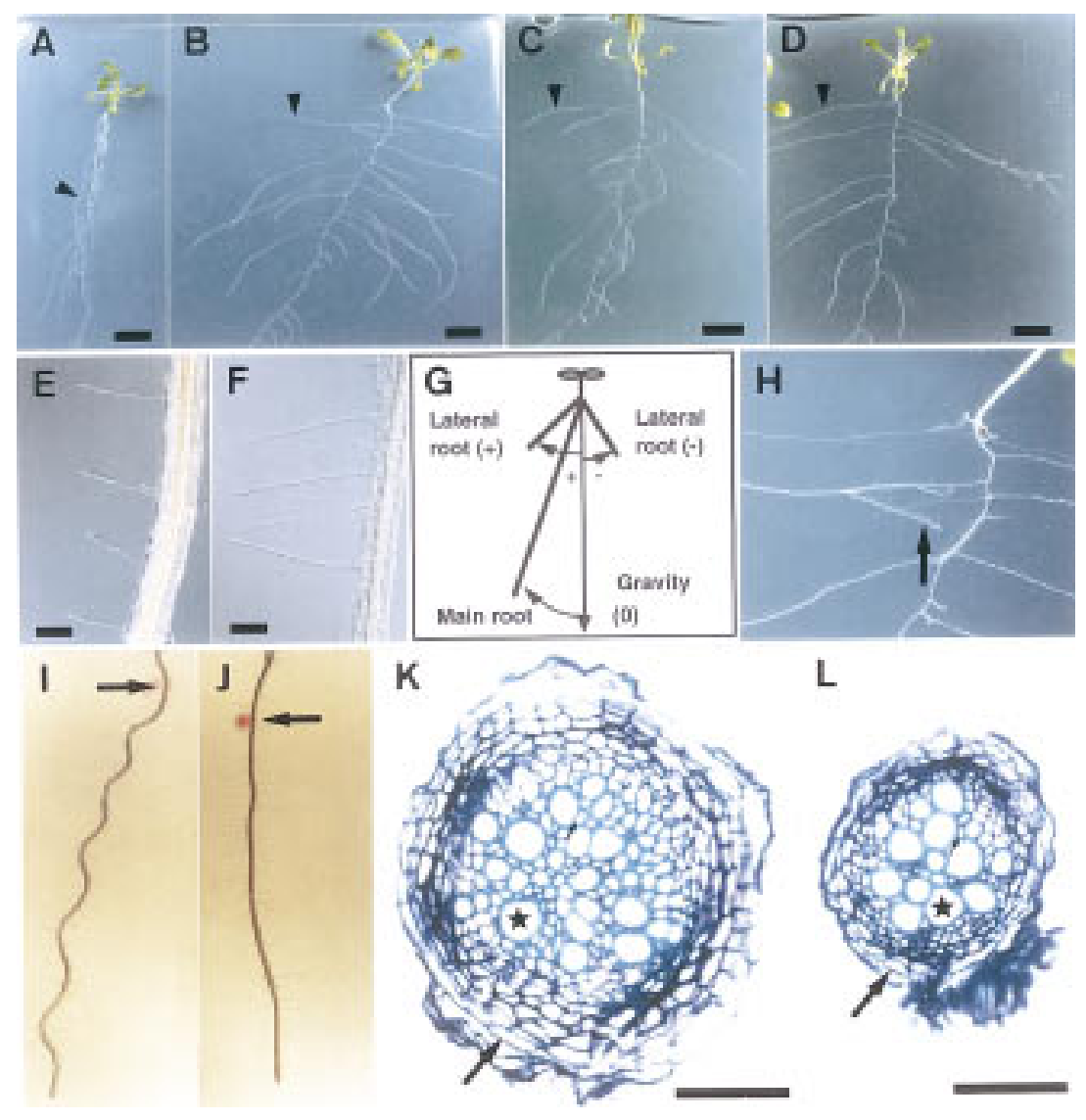

Figure 1. Phenotypes of hy5 mutants. (A-D) Plants at 20 DAG grown on vertically positioned agar plates supplemented with sucrose. Wild-type of Landsberg erecta (Ler) ecotype (A), hy5-1 (B), hy5-Ks50 (C), and hy5-215 (D) are shown. The arrowhead in each panel indicates a lateral root. Scale bars, $10 \mathrm{~mm}$. (E,F) Root hairs of wild-type Ler ecotype (E) and hy5-1 (F). The seedlings were grown on agar plates set in a vertical position. Scal e bars, 100 $\mu \mathrm{m}$. (G) A diagram, indicating how to measure angles formed by roots and gravity orientation. Roots of seedlings elongate on an agar plate set in a vertical position. Plus $(+)$ and minus $(\rightarrow$ degrees represent a clockwise angle from the gravity orientation and a counterclockwise angle, respectively (see Table 3). (H) A magnified view of Fig. $2 \mathrm{~B}$, showing a secondary lateral root of hy5-1 (arrow). $(1, \mathrm{~J})$ Wavy pattern of wild-type of Ler ecotype (I) and hy5-1 (J). Seedlings were grown on an agar plate for 3 days set in a vertical position. Then the plate was tilted to $45^{\circ}$ (arrows indicate the positions of root tips at the time of the position change), and the seedlings were grown for 3 days. $(K, L)$ Cellular organization in the secondarily thickened roots of wild-type Ler ecotype $(\mathrm{K})$ and hy5-1 $(\mathrm{L})$. Transverse sections were made at the same position of main roots of seedlings at 20 DAG grown on agar plates supplemented with sucrose and stained with toluidine blue (see M aterials and M ethods). A well-lignified xylem vessel, a peridremal cell, and a fiber element are indicated by a star, a large arrow, and a small arrow, respectively. Scale bars, $50 \mu \mathrm{m}$. bated on $1.5 \%$ agar plates set at an angle of $45^{\circ}$ from the vertical position, the roots bend al ong the line of gravity but cannot penetrate the agar surface, as they perceive the obstacle-touching stimulus (Okada and Shimura 1990; Simmons et al. 1995). On the angled plates, roots of the wild type grew in a wavy pattern (Fig. 1l); however, roots of hy5-1 grew straight and did not show the wavy pattern (Fig. 1J). This indicates that the hy5 mutation also gives rise to a deficiency in the obstacle-touching response of roots.

The hy5 mutation enhances the initiation and elongation of lateral roots In young seedlings of A rabidopsis, lateral roots originate from pericycle cells that swell and divide periclinally into two cell layers, and the divisions that follow form the lateral root meristem (Dolan et al. 1993; Laskowski et al. 1995; M alamy and Benfey 1997). To examine the frequency of initiation of lateral root formation, we counted the number of lateral root primordia formed in the main root by observation with $\mathrm{N}$ omarski microscopy. Two to three lateral root primordia per seedl ing were detected in wild-type and hy5 mutants of both ecotypes at 2 days after germination (DAG) (Table 4). At 4 DAG, the number of lateral root primordia were not increased in the Landsberg erecta (Ler) wild type but were increased in hy5-1. The number of primor-

Table 1. Length of hypocotyl and epidermal cells of the hypocotyl

\begin{tabular}{|c|c|c|c|}
\hline \multirow[b]{2}{*}{ Allele } & \multicolumn{2}{|c|}{ Hypocotyl length ${ }^{\mathrm{a}}(\mathrm{mm} \pm \mathrm{S.E.})$} & \multirow{2}{*}{$\begin{array}{l}\text { Epidermal cell length } \\
\qquad(\mu \mathrm{m} \pm \mathrm{S} . \mathrm{E} .)\end{array}$} \\
\hline & light & dark & \\
\hline $\begin{array}{l}\text { Wild type (Ler) } \\
\text { hy5-1 }\end{array}$ & $\begin{array}{l}2.06 \pm 0.01 \\
5.38 \pm 0.02(2.6)\end{array}$ & $\begin{array}{l}12.42 \pm 0.03 \\
12.73 \pm 0.03(1.0)\end{array}$ & $\begin{array}{l}156 \pm 14 \\
294 \pm 25(1.9)\end{array}$ \\
\hline
\end{tabular}

N umbers in parentheses indicate the hy5-1/wild-type ratio.

${ }^{a}$ A verage of 17-40 seedlings at 7 DAG in light or darkness.

'DT wo seedlings at 7 DAG of each allele grown on agar plates in the light. Every epidermal cell in a column of hypocotyl cells was measured. 
Table 2. Length of root hairs and root hair-bearing epidermal cells

\begin{tabular}{llc}
\hline Allele & $\begin{array}{c}\text { Root hair } \\
(\mu \mathrm{m} \pm \text { S.E. })\end{array}$ & $\begin{array}{c}\text { Root-hair-bearing } \\
\text { epidermal cell } \\
(\mu \mathrm{m} \pm \text { S.E. }\end{array}$ \\
\hline Wild type (Ler) & $293 \pm 23$ & $183 \pm 8$ \\
hy5-1 & $441 \pm 22(1.5)$ & $221 \pm 16(1.2)$ \\
\hline
\end{tabular}

Numbers in parentheses indicate the hy5-1/wild-type ratio. Seedlings were grown on agar plates in the light for 7 days. ${ }^{2}$ A verage of 38 (Ler) or 11 (hy5) root hairs located $>0.5 \mathrm{~mm}$ distant from the root tip.

${ }^{\mathrm{b}} \mathrm{A}$ verage of 36 (Ler) or 27 (hy5) root hair-bearing epidermal cells.

dia were increased in the Wassi lewskija (Ws) wild type at 4 DAG, but the increase was two times greater in the hy5-Ks50 mutant than in Ws (Table 4). Growth rates of the main root of the hy 5 mutants were about the same as those of the wild-type plants ( $T$ able 4 ). The el ongation of lateral roots was al so enhanced in the hy 5 mutant. Table 3 shows the length of main roots and lateral roots of Ler wild-type and hy5-1. The lateral roots of hy5-1 were about twice as long as those of the wild type, whereas the length of the main root of hy5-1 was about the same as that of the wild type. These results indicate that the hy 5 mutation enhances the initiation of lateral root primordia and their growth.

The hy 5 mutation reduces the secondary thickening of the root and hypocotyl Roots of Arabidopsis grow thicker through successive cell proliferation, termed secondary thickening. The secondary cell growth occurs acropetally. As shown in Figure $1 \mathrm{~K}$, the main root of a typical wild-type plant at 20 DAG was $0.2 \mathrm{~mm}$ in diameter at $\sim 0.5 \mathrm{~cm}$ bel ow the root-hypocotyl joint. The cell walls of many oval-shaped xylem vessels were widely lignified, and angular fiber el ements were present in the spaces among the vessels (Fig. 1K, small arrow). Thick peridermal cells surrounded the root (Fig. 1K, large arrow). Compared with that of the wild type, the main root of the hy 5 mutant at the same age showed a decreased amount of secondary cell proliferation. As shown in Figure $1 \mathrm{~L}$, the number of lignified oval-shaped xylem vessels was decreased to $\sim 60 \%$ of the wild-type number. In addition, angular fiber el ements were hardly developed, and the size of peridermal cells was smaller than that of the wild-type ones.

The hypocotyl of the A rabidopsis plant al so undergoes secondary thickening. At $20 \mathrm{DAG}$, the hypocotyl of the wild-type plant was $\sim 0.5 \mathrm{~mm}$ in diameter. The hy $5 \mathrm{mu}-$ tant showed reduced secondary thickening of the hypocotyl, with a hypocotyl diameter of $\sim 50 \%$ of that in the wild type at the same stage. The number of Iignified xylem vessels and fiber el ements was reduced in the hypocotyl of the mutant as well (data not shown).

The hy 5 mutation reduces greening of the hypocotyl and root In the hypocotyl of light-grown A rabidopsis seedlings, chloroplasts are well developed. As shown in Figure $2 \mathrm{~A}$, the morphology and distribution of chloroplasts of the hy5 mutant were indistinguishable from those of wild type only at the upper part of the hypocotyl. However, a reduced number of chloroplasts, which were pale green, were observed at the middle part of the mutant. In the lower part of the hypocotyl, the number of chloropl asts was reduced in wild-type plants; however, the hy5 mutant showed only a few small and transparent plastids.

Roots of wild-type plants turn green when grown under the light. As shown in Figure 2B, the roots of wildtype plants were green (panel a); whereas those of hy5 mutants (panels $b, c$ ) remained white after having been cultured for 30 days under light. It is known that chloroplast development is enhanced in roots of seedlings of cop1 mutants (Deng and Quail 1992). Liquid-cultured roots of cop1-6 showed greening (Fig. 2B, panel d). The chlorophyll content in roots of the wild-type plant (Ws) was $1.1 \mu \mathrm{g}$ of chlorophyll/gram of fresh roots (See Materials and Methods). Chlorophyll was not detected in roots of hy5-1 or hy5-Ks50. Roots of cop1-6 contained $\sim 20$-fold the amount of chlorophyll of the wild type. Thus, the hy 5 mutation has an inhibitory effect on the greening of roots, which is opposite that of the copl mutation.

\section{Molecular characterization of the HY 5 gene}

Molecular cloning of the HY5 gene To understand the molecular mechanism of the HY5 gene, we cloned the

Table 3. Angles (degree \pm S.E.) formed by roots and gravity orientation plus root length (cm \pm S.E.)

\begin{tabular}{|c|c|c|c|c|c|c|}
\hline \multirow[b]{2}{*}{ Allele } & \multicolumn{2}{|c|}{ Main roots } & \multicolumn{2}{|c|}{ Lateral roots (+) } & \multicolumn{2}{|c|}{ Lateral roots $(-)$} \\
\hline & angle & length & angle & length & angle & length \\
\hline $\begin{array}{l}\text { Wild type (Ler) } \\
\text { hy5-1 }\end{array}$ & $\begin{array}{l}16.2 \pm 1.0 \\
32.8 \pm 1.3(2.0)\end{array}$ & $\begin{array}{l}3.93 \pm 0.18 \\
3.72 \pm 0.14(0.95)\end{array}$ & $\begin{array}{l}24.5 \pm 2.8 \\
81.5 \pm 3.3(3.3)\end{array}$ & $\begin{array}{l}1.03 \pm 0.10 \\
1.91 \pm 0.15(1.85)\end{array}$ & $\begin{aligned}-9.7 & \pm 1.9 \\
-62.4 & \pm 8.1(6.4)\end{aligned}$ & $\begin{array}{l}0.95 \pm 0.08 \\
2.08 \pm 0.10(2.19)\end{array}$ \\
\hline
\end{tabular}

N umbers in parentheses indicate the hy5-1/wild-type ratio. Sample numbers of wild-type (Ler) and hy5-1 were 30 and 36 , respectively. Seedl ings at 7 DAG (main roots) or 10 DAG (lateral roots) grown in the light on agar plates supplemented with sucrose were examined. $M$ ain roots and the longest lateral roots on each side were measured. The measurement procedures of the angles are explained in the legend of Fig. $2 \mathrm{G}$. 
Table 4. Number of lateral root primordia and length of main roots

\begin{tabular}{|c|c|c|c|c|}
\hline \multirow[b]{2}{*}{ Allele } & \multicolumn{2}{|c|}{ Seedlings at $2 \mathrm{DAG}$} & \multicolumn{2}{|c|}{ Seedlings at 4 DAG } \\
\hline & $\begin{array}{l}\text { number of Iateral } \\
\text { root primordiaa }\end{array}$ & $\begin{array}{l}\text { main root } \\
\text { length }(\mathrm{cm})\end{array}$ & $\begin{array}{c}\text { number of Iateral } \\
\text { root primordia }\end{array}$ & $\begin{array}{l}\text { main root } \\
\text { length }(\mathrm{cm})\end{array}$ \\
\hline Wild type (Ler) & 2.0 & 0.90 & 1.3 & 1.53 \\
\hline hy5-1 & $2.0(1.00)$ & $0.66(0.73)$ & $3.7(2.85)$ & $1.18(0.77)$ \\
\hline Wild type (Ws) & 2.7 & 1.22 & 4.3 & 2.11 \\
\hline hy5-Ks50 & $3.0(1.11)$ & $1.30(1.07)$ & $8.3(1.93)$ & $1.97(0.93)$ \\
\hline
\end{tabular}

A verage of three seedlings of each allele grown on agar plates in the light is shown. N umbers in parentheses indicate the hy5-1/wildtype ratio. The ecotypes of hy5-1 and hy5-Ks50 are Ler and Ws, respectively.

aprimordia showing two or more cell layers were counted.

gene using the hy5-Ks50 line. The genomic sequence around the T-DNA insertion site is shown in Figure 3A. The longest cDN A clone was $842 \mathrm{bp}$, which is close to the estimated mRNA size, $0.9 \mathrm{~kb}$, by Northern blot analysis (data not shown). The gene, which was divided into four exons, covered a $1.5-\mathrm{kb}$ genomic region. To confirm that the genomic region included the HY 5 gene, we introduced a 4.5-kb Pstl-digested fragment (one of the Pstl sites is shown in Fig. 3A) into hy5-Ks50 mutants. The transformants showed the same hypocotyl length as found in the wild type in white light, normal growth pattern in the root, and normal secondary thickening and greening of the root and hypocotyl (Fig. 3C). The complemented phenotype of the mutant thus indicated that the introduced genomic fragment included the whole region of the HY5 gene.

The HY5 locus encodes a protein with a bZIP motif The longest open reading frame (ORF) in the HY5 cDNA clones encoded a protein of $18.5 \mathrm{kD}$ composed of 168 amino acid residues (Fig. 3A). A comparison of the amino acid sequence with available databases revealed the carboxy-terminal half of the HY 5 protein to be homologous to a DNA-binding and dimerization domain of bZIP-Class proteins (Fig. 3B). The sequences at the other regions were not found in other bZIP proteins except STF1A, which was isol ated from soybean (Y.-H. Cheong and J.-C. Hong, pers. comm.). STFIA protein showed high similarity to HY 5 in the amino- and carboxy-terminal regions, including the bZIP domain (Fig. 3B). The amino acid sequence in the basic regi on was completely identical between HY5 and STF1A proteins. The two proteins contained five heptad repeats of leucine, and only three amino acid residues are different in the leucine zipper regi on. In addition, there was a casein kinase II (CKII) phosphorylation site (S/TXXE/D, rich in acidic amino acids) (Pearson and Kemp 1991) in a highly conserved region from E-35 to E-49 of the HY 5 protein (Fig. 3B). Genomic Southern analysis using HY 5 CDN A as the probe showed a single band corresponding to the HY5 gene under high stringency conditions and several weak bands under low stringency conditions, indicating that there are no genes highly homol ogous to the HY 5 genein the genome of Arabidopsis (data not shown).
Molecular lesions in the three hy5 mutant genes Molecular lesions in three hy5 mutant alleles, hy5-Ks50, hy5-1, and hy5-215, were determined by sequencing the hy5 loci. In the genome of hy5-Ks50, the insertion of a
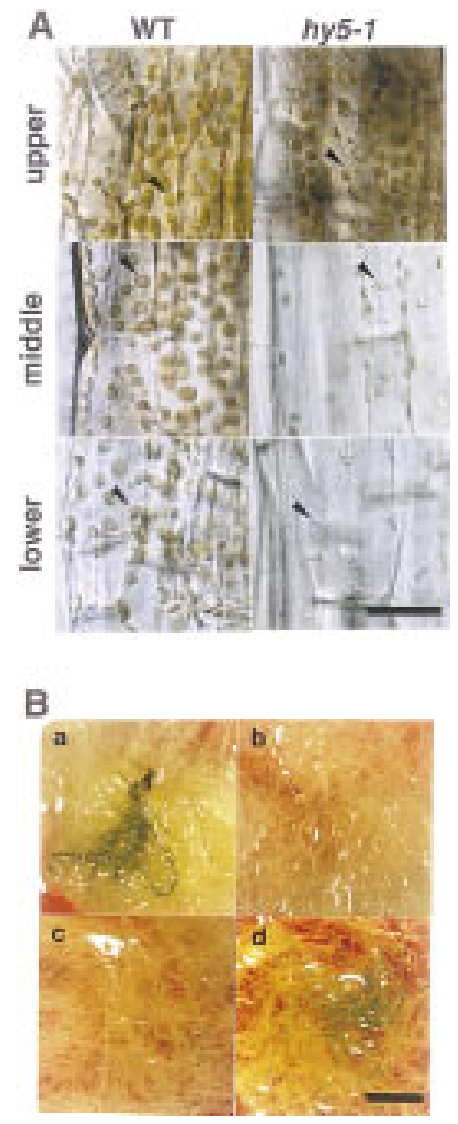

Figure 2. Greening in the hypocotyl and roots. (A) Chloroplasts in the hypocotyl of wild-type Ler ecotype (left) and hy5-1 (right) plants at 20 DAG grown on agar plates supplemented with sucrose. Upper, middle, and lower parts of the hypocotyl are shown in respectively labeled panels. Scale bar, $25 \mu \mathrm{m}$. (B) Roots of plants at 30 DAG grown in a liquid medium. Leaves and the hypocotyl are removed from the plants. Wild-type of Ler ecotype (a), hy5-1 (b), hy5-Ks50 (c), and cop1-6 (d) are shown. Scale bar, $10 \mathrm{~mm}$. 
Figure 3. Sequence analysis of the HY5 gene. (A) Genomic DN A sequence and deduced amino acid sequence of HY5. The genomic sequence from Sacl to Pstl in the HY5 locus of the Ws wild type is shown. The first $\mathrm{G}$ in the Sacl site is designated as number 1 . N umbers in ital ics indicate the amino acid sequence of the HY 5 protein. Exons are shown in uppercase letters. The bZIP domain is underlined. In hy5-Ks50, sequences between $\mathrm{t}-147$ and t-935 nucleotides (in boldface at arrowheads) are deleted and a T-DNA concatemer is inserted. In hy5-1, the nucleotide C-811 (white letter) is replaced by $\mathrm{T}$, which results in a stop of translation. In hy5-215, the nucl eotide g-1117 (white letter), which is the last nucleotide in the first intron, is replaced by an a. The HY 5 cDN A sequence has been deposited in DDBJ/GenBank/ EMBL databases (accession no. AB005295). (B) Amino acid comparison of plant bZIP proteins. The deduced HY5 amino acid sequence is compared with the sequences of eight related proteins in plants: STF1A from soybean (GenBank accession no. L28003, J.-C. Hong, pers. comm.), TGA-1b and TGA-1a from tobacco (Katagiri et al. 1989), EmBP-1 from wheat (Guiltinan et al. 1990), HBP-1a and HBP-1b from wheat (Tabata et al. 1989, 1991), GBF-1 from Arabidopsis (Schindler et al. 1992a), and OPAQUE2 from maize (Hartings et al. 1989; Schmidt et al. 1990). White letters represent residues identical to the HY 5 sequence. A serine residue that is predicted to be phosphorylated by CKII is indicated $(\bigcirc)$. The basic region (from $\mathrm{K}$ 90 to K-109) is overlined. (-) The heptad repeat of leucines in the leucine zipper region. Asterisks $(*)$ indicate the carboxylterminus of a given protein. (C) Complementation of hy5-Ks50 with a genomic sequence including the HY5 gene. (Left) Plants at 20 DAG grown in the light on a vertically positioned agar plate supplemented with sucrose. The plants are wildtype of Ws ecotype, hy50-Ks50 transformed with the genomic sequence, and hy5-Ks50 (from left to right). Leaves were removed from the plants. Scale bar, 10 $\mathrm{mm}$. (Right) Bar graph of hypocotyl lengths of seedlings at 7 DAG grown in the light. The bars represent wild-type of Ws ecotype, hy5-Ks50 transformed with the genomic sequence, and hy5-Ks50, respectively. N umbers of the measured samples are 18 (wild-type) or 40 (the transformant and hy5-Ks50).
A
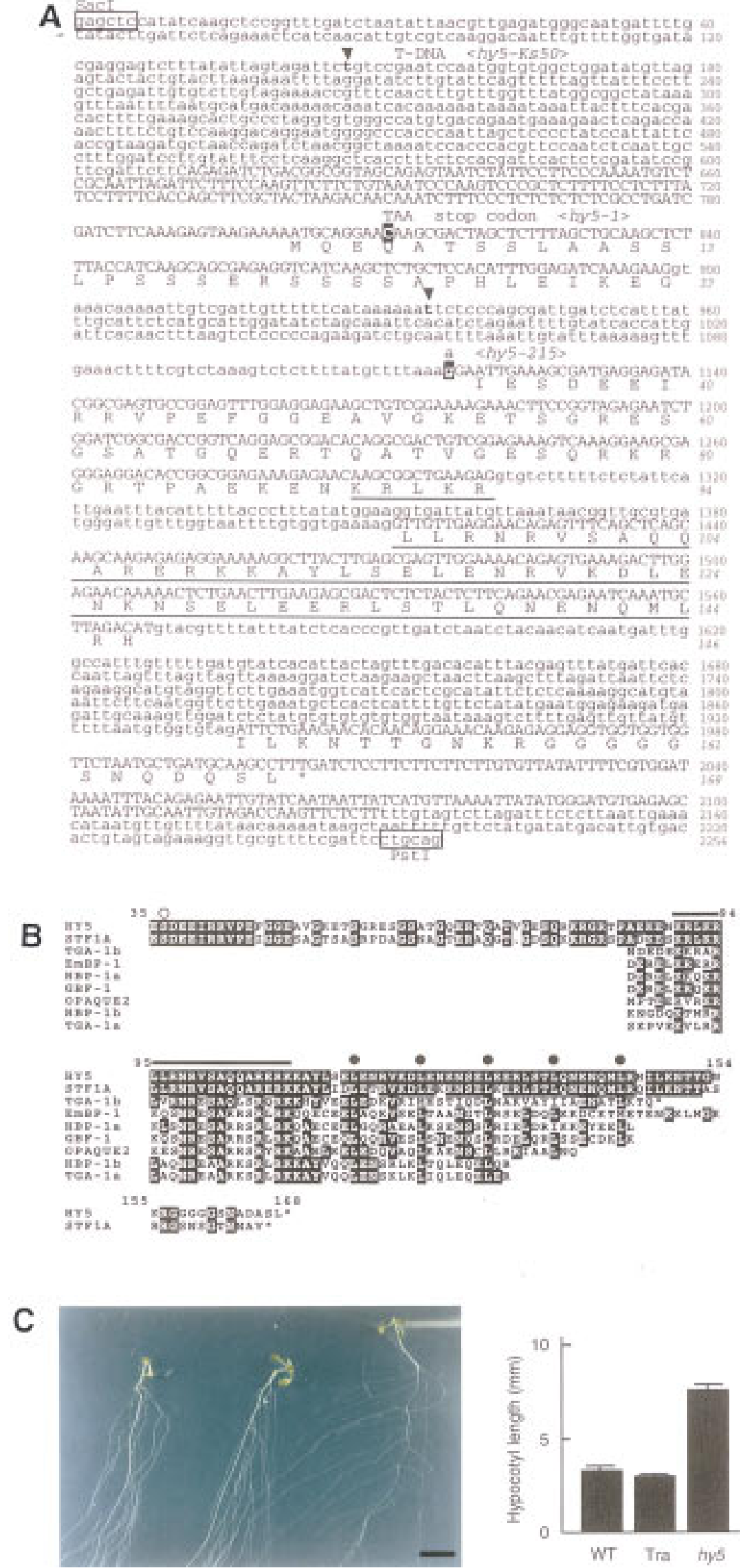


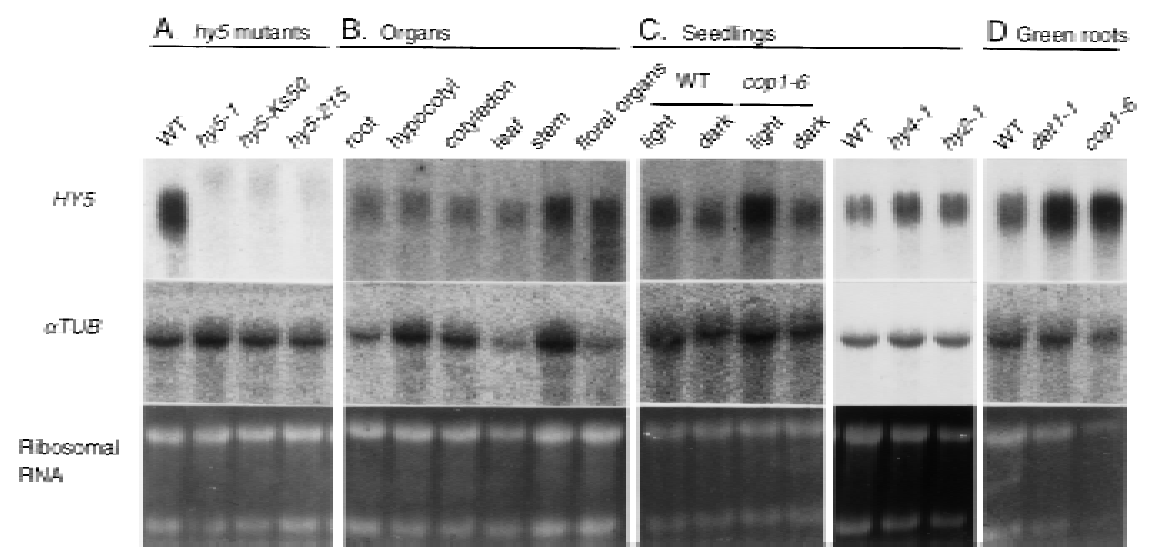

Figure 4. N orthern blot analysis of HY5 mRNA. An aliquot of the total RNA (10 $\mu \mathrm{g} /$ lane) was subjected to agarose gel electrophoresis, transferred to nylon membranes, and hybridized with the probe of HY 5 CDNA, as described in Materials and $M$ ethods. The same membranes were subsequently hybridized with the probe of the $\alpha$ TU BU LIN ( $\alpha$ TUB) coding region of Arabidopsis (Kopczak et al. 1992). rRN A was detected by staining gels with ethidium bromide. (A) Total RNA was extracted from roots of plants at 30 DAG grown in a liquid medium. (B) The total RNA was extracted from root, hypocotyl, and cotyledon tissues isolated from light-grown seedlings of wild-type (Ler) at 3 DAG on agar plates supplemented with sucrose. Leaf, stem, and floral organs were isolated from mature wild-type plants grown in soil. Samples of the floral organs contained different tissues of the inflorescent meristem, floral buds, and mature flowers. (C) T otal RN A was extracted from light- and dark-grown seedl ings of wild-type Ler ecotype and the cop1- 6 mutant or from light-grown seedl ings of the hy2 and the hy4 mutants. All seedl ings were grown on agar plates supplemented with sucrose for 3 days. (D) Total RN A was extracted from roots of plants at 30 DAG of each genotype grown in a liquid medium.

T-DN A concatemer was accompanied by a deletion of a 790-bp region including the first exon and 5 ' upstream region of the HY5 gene. In the genome of hy5-1, the fourth codon $(C A A=Q)$ was substituted for a stop codon (=TAA). In the genome of hy5-215, the splicing acceptor site of the first intron $(=\mathrm{G})$ (Padgett et al. 1986) was replaced by $A$, suggesting that this mutation causes aberrant RNA processing. As shown in Figure 4A, HY5 mRN A did not accumulate in the three mutants. Therefore, all three mutants may have no functional HY 5 gene product and can be considered to be null alleles.

Expression patterns of the HY5 gene In the wild-type plant, HY 5 mRN A was accumulated in all tissues examined: root, hypocotyl, cotyledon, leaf, stem, and floral

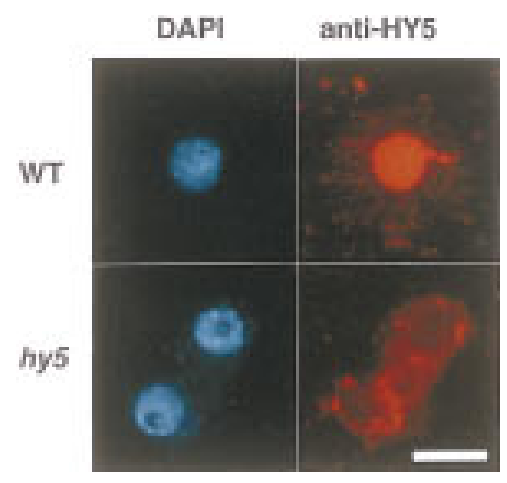

Figure 5. Subcellular localization of the HY5 protein. Protoplasts were prepared from roots of seedlings at 7 DAG grown on agar plates supplemented with sucrose in the light. The top and bottom panels show the wild-type Ws ecotype and hy5-Ks50, respectively. The left and right panels show DAPI staining of the nuclei and Texas Red imaging of the same cells detected with anti-HY 5 antiserum, respectively. Scale bar, $10 \mu \mathrm{m}$. organs (Fig. 4B). To examinethelight dependency of HY5 expression, we examined accumulation levels of HY5 mRNA in seedlings of wild-type, copl- 6 grown in the light and in darkness, and hy2-1 and hy4-1 grown in the light. It is known that copl-6 mutants show photomorphogenesis in darkness (M cN ellis et al. 1994). As shown in Figure 4C, HY5 mRNA accumulated in wild-type seedlings to an extent approximately two times greater in the light than in darkness, indicating that the expression of the HY5 gene is induced by light. In cop1-6, the level of HY5 mRNA was higher than that in the wild type, and the enhanced accumulation in the light was also observed. The accumulation levels of HY5 mRNA in light- and dark-grown seedl ings of cop1-6 were $\sim 2$ and 1.6 times, respectively, as high as those of wild-type seedl ings. This indicates that the accumulation of HY5 mRNA in seedlings is modulated by the COP1 gene. However, the accumulation levels of HY5 mRNA in light-grown hy2-1 and hy4-1 seedlings were about the same as that in wild type (Fig. 4C). The two mutants show a long hypocotyl, like the hy5 mutant, in white light because the hy2 and hy 4 mutants are defective in the phytochrome (Koornneef et al . 1980; Parks and Quail 1991) and in a bluelight receptor named CRY1 (A hmad and Cashmore 1993; Lin et al. 1995), respectively. These results suggest that the induction of the HY5 gene by light may require photoreceptors other than the phytochrome and CRY 1 . In roots of plants at 30 DAG grown in a liquid medium, cop1-6 and det1-1 accumulated approximately five and three times higher levels of HY 5 mRNA, respectively, than the wild type (Fig. 4D), indicating that both COP1 and DET1 genes repress the expression of the HY5 gene in roots of wild-type.

The HY 5 protein is localized in the nucleus To confirm the possibility that the HY 5 protein works as a transcription regulatory factor, we examined the subcellular lo- 
Oyama et al.

Table 5. Classification of phenotypes of the hy5 mutant

\begin{tabular}{|c|c|c|}
\hline Group & Phenotype & $\begin{array}{l}\text { Physical stimulus } \\
\text { related to the phenotype }\end{array}$ \\
\hline Cell elongation & $\begin{array}{l}\text { enhanced hypocotyl el ongation } \\
\text { enhanced root hair el ongation } \\
\text { aberrant gravitropic response of roots } \\
\text { no waving growth of roots }\end{array}$ & $\begin{array}{l}\text { light } \\
\text { touching } \\
\text { gravity } \\
\text { touching }\end{array}$ \\
\hline Cell proliferation & $\begin{array}{l}\text { enhanced lateral root elongation } \\
\text { enhanced lateral root initiation } \\
\text { reduced secondary thickening }\end{array}$ & $\begin{array}{l}\text { none } \\
\text { none } \\
\text { none }\end{array}$ \\
\hline Chloroplast development & reduced greening of root and hypocotyl & light \\
\hline
\end{tabular}

calization of the HY5 protein. The HY5 protein was stained with anti-HY5 antiserum. In protoplasts prepared from roots of wild-type seedlings, signals of antiHY 5 stai ning overlapped with the DAPI staining signals, indicating that the HY5 protein is localized in the nucleus (Fig. 5, top panels). In protopl asts prepared from hy5-Ks50, however, signals of background level were detected in the cytoplasm (Fig. 5, bottom panels). It will be necessary to examine whether the basic region of the HY 5 protein works as a nuclear localization signal, because the sequence of the basic regi on of the HY 5 protein is different from those of several plant bZIP proteins, including TGA-1a, TGA-1b, and OPAQUE2, which have been shown to act as a nuclear localization signal (for review, see Foster et al. 1994).

\section{Discussion}

The HY5 gene was shown earlier to be a positive regulator of photomorphogenesis of young seedl ings (Koornneef et al. 1980; Chory 1992; Ang and Deng 1994). Detailed characterization of the mutant phenotype has revealed that the hy5 mutant is defective in various aspects of morphogenesis and stimulus responses in the hypocotyl and root. The pleiotropic phenotypes can be classified under three criteria: whether the phenotype is mainly related to cell elongation, to cell proliferation, or to chloroplast development (Table 5).

The first group includes four phenotypes. Gravitropic and touching responses of roots are placed in the first group because these responses are thought to be a consequence of regulation of cell elongation (Wilkins 1966; Okada and Shimura 1994). It has been shown that the length of root hairs is affected by the touching stimulus (Okada and Shimura 1994). Although the type of stimuIus is different, the four phenotypes appear to be based on aberrant cell elongation. Therefore, we propose that one of the molecular functions of the HY5 gene is negative regulation at some common step(s) of the intracellular signal transduction pathways that mediate signals triggered by different physical stimuli for cell elongation.

The second group includes three phenotypes: Iateral root elongation, lateral root initiation, and secondary thickening. The lateral root el ongation appears to be related to cell el ongation. However, the length of mature cells in the lateral roots of the hy 5 mutant was about the same as that of the wild type, indicating that the enhanced lateral root elongation of the mutant may be caused by enhanced cell proliferation in the meristem. The hy 5 mutation al so promoted the initiation of Iateral roots, suggesting that the differentiation from pericycle cells to a lateral root primordium may be enhanced in the mutant. Because the structure of lateral root primordia of the mutant looked similar to that of the wild type, the HY5 gene is likely to control the initiation by re pressing the cell proliferation in wild-type plants. In the secondary thickening of root and hypocotyl, the HY5 gene is likely to promote or maintain the meristimatic activity in the vascular cambial cells that proliferate and differentiate into xylem and fiber elements. Thus, the HY 5 gene controls cell proliferation positively in the secondary thickening, and negatively in the lateral root formation. HY5 may regulate cell division in a tissue-specific manner. Interestingly, the three phenotypes in the second group are not directly related to environmental stimuli; however, they are possibly stimulated by endogenous nutrition conditions or balance of phytohormones.

The third group incl udes a phenotype of the deficiency of greening of root and hypocotyl. The HY 5 gene is likely to promote chloroplast development in the root and hypocotyl, possibly stimulated by light, as in cotyledons and leaves. Because the chl oroplast development in roots of wild-type plants is usually accompanied by secondary thickening, the phenotype of reduced greening in the hy5 mutant may be dependent on the reduced secondary thickening in roots. It is worthy to note that the hy5 mutation also gives rise to a reduced gravitropic re sponse, longer root hairs, and enhanced lateral root formation in darkness (data not shown). This indicates that the HY5 gene is likely to play roles in the root growth and the gravitropic response independent of the light signal.

Our molecular anal ysis has reveal ed that the HY5 gene encodes a bZIP protein localized in the nucleus. Many bZIP proteins have been isol ated from various plant species. In many cases, the bZIP proteins bind to DN A containing an ACGT core sequence. Although the ACGT sequence is known as a core motif for cis-acting elements in promoters of various stimulus-responsive 
genes in plants, the physiological roles of bZIP class trans-acting factors have been demonstrated only in some cases (for review, see Foster et al . 1994; M enkens et at. 1995). M any of the plant bZIP proteins contain extra domains such as a proline-rich region, acidic region, or glutamine-rich region, in addition to the bZIP domain. A proline-rich region of the Arabidopsis GBF1 protein was shown to have the activity of transcriptional activation (Schindler et al. 1992b). Highly acidic regions are a common feature of transcriptional activators in eukaryotes (Cress and Triezenberg 1991). The HY5 protein has no obvious domains except the bZIP domain. The lack of potential transcriptional activation domains implies that the HY 5 protein may not work as a transcriptional activator. The amino acid sequence of this protein from E-35 to the last amino acid residue shares $70 \%$ identity with the STFIA protein of soybean, and the basic region of the HY 5 protein is completely identical to that of the STF1A protein. The STF1A protein preferentially binds to DNA sequences containing a TGACGT core, and it weakly binds to DN A sequences containing a $G$ box $(Y$.$\mathrm{H}$. Cheong and J.-C. Hong, pers. comm.). A crystallographic study on GCN 4 (a yeast bZIP protein)/DNA complex clearly showed that the basic region interacts with the target DN A (Ell enberger et al. 1992). M oreover, the amino acid sequence of the basic region in bZIP proteins was shown to specify the target nucleotide sequence (Suckow et al. 1993). Therefore, the complete identity of basic regions between the HY 5 protein and the STF1A protein strongly suggests that the HY 5 protein likely binds to the same DNA sequences as the STF1A protein. In addition, a region from E-35 to E-49 of the HY 5 protein is highly homologous to that of the STF1A protein (Fig. 3B). This region contains a consensus sequence for phosphorylation by CKII. Because phosphorylation of an Arabidopsis bZIP protein, GBF1, by CKII was shown to stimulate its DNA-binding activity (Klimczak et al. 1992), phosphorylation at the putative CKII phosphorylation sites of the HY 5 and STF1A proteins may enhance their DNA-binding activity.

As discussed above, the HY 5 protein is likely to have roles as a transcriptional regulatory factor in a wide variety of stimulus responses and developmental processes in the hypocotyl and root. As for the molecular mechanism governing HY 5 protein function, studies on photomorphogenesis of young seedlings have provided useful information because molecular genetic data on the HY5 gene and other genes have been accumulated (for review, see C hory 1993; Deng 1994; M cN el lis and Deng 1995). In the mechanism of hypocotyl elongation of light-grown seedlings, it has been proposed that the HY 5 protein works as a positive regulator downstream of photoreceptors in the signaling pathway (Koornneef et al. 1980; Chory 1992; Ang and Deng 1994). In addition to the HY5 gene, the DET1 and COP1 genes al so work downstream of photoreceptors in light-signaling pathways, however, as negative regulators (Chory et al. 1989b; Deng et al. 1991; Chory 1992; Ang and Deng 1994). Both DET 1 and COP1 proteins have been shown to be localized in the nucleus, and they negatively regulate expression of light- induced genes in dark-grown seedlings (Pepper et al. 1994; von Arnim and Deng 1994). Because the HY 5 protein is also localized in the nucleus and likely acts as a transcriptional regulatory factor, these three proteins may be associated with a common transcription compl ex that regulates the expression of light-induced genes. It has been reported that several light-regulated genes contain the ACGT sequence as a light-responsive cisacting element in their promoters (Batschauer et al. 1994), suggesting that HY 5 may bind directly to those promoters. Interestingly, HY 5 mRN A was accumulated at a higher level than wild type in roots of both det 1 and cop1 mutants. Thus, the amount of the HY 5 gene product is likely to be modulated by the DET1 and COP1 genes. Because the det1 and copl mutants show excess chloropl ast devel opment in their roots-just the reverse effect of the hy5 mutant (Chory and Peto; Deng and Quail 1992)-the DET1 and COP1 genes may repress chloroplast development in the root of the wild type by repressing the expression of the HY5 gene.

As discussed above, hy5 is a unique mutant because it shows pleiotropic effects on a variety of stimulus responses and on the development of both root and hypocotyl. As a similar mutant with a wide range of phenotypes, the diagi otropica (dgt) mutant was isolated from the tomato (Zobel 1974). The dgt mutant shows diageotropism in both shoots and roots and, interestingly, al so shows morphological defects, that is, it lacks large secondary xylem vessels in the stem and shows a loss of lateral roots and an open hypocotyl hook. Although not all of the phenotypes of the dgt mutant coincide with those of the hy5 mutant, the resemblance of phenotypes between the two mutants suggests that they affect common signaling pathways in the tomato and in Arabidopsis. Interestingly, the dgt mutant is also known to be insensitive to auxin (Kelly and Bradford 1986). It is known that auxin mediates gravitropism and lateral root formation (Wilkins 1966; Juniper 1976; Boerjan et al. 1995; Laskowski et al. 1995). In addition, auxin is likely to be involved in cambium proliferation and secondary thickening (Wareing and Phillips 1981). As summarized in Table 5, the HY 5 gene is involved not only in the light response but also in gravitropic and touching responses and the process of secondary thickening, in which auxin plays an important role. Therefore, it could be argued that the HY 5 protein may be involved in the signaling pathway mediated by auxin and may regulate expression of auxin-induced genes. It has been shown that the promoter of the soybean GH3 gene contains TGACGT elements that confer the auxin inducibility (Liu et at. 1994). Further investigation of molecular mechanisms underlying how the HY 5 protein perceives stimulus-induced signals and how the HY 5 protein controls the expression of the target genes will unravel the role of the HY 5 gene in the development and signaling pathways in plants.

\section{Materials and methods}

Plant materials and growth conditions

Mutant lines hy2-1, hy4-1, and hy5-1 were obtained from the 
Arabidopsis Biological Resource Center (The Ohio State University, Columbus, $\mathrm{OH})$. The ecotype of the mutants is Ler. The cop1-6, det1-1, and hy5-215 (Columbia background) were provided by Y. Komeda (Hokkaido University, Sapporo, Japan), J. Chory (The Salk Institute, San Diego, CA), and X.-W. Deng (Yale University, N ew Haven, CT), respectively.

Plants were grown on agar plates under conditions described previously (Okada and Shimura 1992b). In several experiments, the agar medium was supplemented with 20 grams/liter of sucrose. For the liquid culture of plants, sterilized seeds were germinated and cultured with gentle shaking $(60 \mathrm{rpm})$ in a liquid medium containing $1 \times$ Gamborg's B5 medium salt mixture ( $\mathrm{Ni}$ hon-Seiyaku, Co., Ltd. Tokyo, Japan) and 20 grams/liter of sucrose, adjusted to $\mathrm{pH} 5.7$ with $\mathrm{KOH}$, at $22^{\circ} \mathrm{C}$ under white light of $50-100 \mu \mathrm{E} / \mathrm{m}^{2}$ per sec.

\section{Isolation of hy5-Ks50}

hy5-Ks50 was isolated from T-DNA insertion lines that were produced by the in planta transformation method devel oped by Chang et al. (1994) and modified by T. Ohsumi and R.F. Whittier (pers. comm.). An Agrobacterium tumefaciens strain, C58C 1::rif, carrying an intermediate type $\mathrm{Ti}$ plasmid vector, pGV3850::hyg, was kindly provided by Mitui Plant Biotechnology Institute and was used to infect Ws wild-type plants (TO plants). The seeds of T0 plants were harvested and sown on a sel ection medium containing $1 \times$ Gamborg's B5 salt mixture [pH 5.7 with $\mathrm{KOH}, 1 \%$ sucrose, $10 \mathrm{mg} /$ liter of hygromycin B (Wako Pure Chemical Industries, Ltd., Osaka, Japan)], and 8 grams/ liter of agar. Seedlings showing the hygromycin resistance (T 1 plants) were transplanted to soil, and the seeds (T2 seeds) were harvested from each $\mathrm{T} 1 \mathrm{plant}$. M utants were screened from the $\mathrm{T} 2$ lines. A recessive mutant line, $\mathrm{Ks} 50$, was isolated and showed the long hypocotyl phenotype. That line was subjected to an allelism test with hy1-1, hy2-1, phyB-1, hy4-1, and hy5-1 (Koornneef et al. 1980) and was shown to be allelic to the hy5 mutant (data not shown). We therefore designated Ks50 as hy5Ks50.

\section{Count of lateral root number}

Two DAG and four DAG seedlings were fixed in $4 \%$ paraformal dehyde in PBS and inspected under an Olympus Provia AX70 microscope.

\section{Sectioning and microscopy}

Secondarily thickened roots were fixed for $12 \mathrm{hr}$ in $4 \%$ paraformal dehyde in PBS. Fixed samples were dehydrated in a series of $50 \%$ (ice-cold), $90 \%, 100 \%, 100 \%$ ethanol (30 min in each step), an ethanol-tert-butanol series, 3:1, 1:1, 1:3, then through two changes of $100 \%$ tert-butanol (20 min in each step). The samples were passed through paraffin (solidifying point $51^{\circ} \mathrm{C}-$ $53^{\circ} \mathrm{C}$; Merck, Darmstadt, Germany)-tert-butanol of $1: 1$ and $100 \%$ paraffin at $55^{\circ} \mathrm{C}$ for $1 \mathrm{hr}$ in each step, and embedded in $100 \%$ paraffin. Eight-micrometer sections were made on Erma 02631A microtome (Erma, Tokyo, Japan). Sections were stained in $0.05 \%$ toluidine blue (Kodak) and inspected under an Olympus Provia AX70 microscope.
Measurement of chlorophyll content

Roots of plants at 30 DAG grown in liquid medium were homogenized in $80 \%$ acetone in a Potter-Elvehjem-type glass homogenizer. The homogenate was centrifuged, and absorbance spectrum of the supernatant was measured. Two plants of each allele were measured. Total chlorophyll contents were calculated according to the following equation (Arnon 1949): total chlorophyll $(\mu \mathrm{g} / \mathrm{ml})=8.02\left(\mathrm{~A}_{663}-\mathrm{A}_{710}\right)+20.2\left(\mathrm{~A}_{645}-\mathrm{A}_{710}\right)$.

\section{Molecular analysis}

Standard protocols were used for enzyme reactions, DNA blotting, and RN A blotting (Sambrook et al. 1989). DN A and RN A were isolated from plants by the methods described by Ausubel et al . (1987). In Southern analysis, plaque, and col ony screening, the blotting was done onto nylon membranes (Hybond- $\mathrm{N}$, Amersham), and hybridization was performed with a solution [5x SSC, $1 \%$ blocking reagent (Boehringer $\mathrm{M}$ annheim), $0.1 \% \mathrm{~N}$-lauroylsarcosine, $0.02 \% \mathrm{SDS}$ ] at $65^{\circ} \mathrm{C}$ containing a probe, and washing was performed under stringent conditions $(1 \times \mathrm{SSC}, 0.1 \%$ $\mathrm{SDS}$ ) at $65^{\circ} \mathrm{C}$. Probes were labeled with $\left[{ }^{32} \mathrm{P}\right] \mathrm{dCTP}$ (Amersham) by use of a random primer DNA labeling kit (Takara Shuzo, Ohtsu, Japan). Autoradiographs were scanned and analyzed with a Bio-Imaging Analyzer (BAS 1000 or 2000, Fuji). In N orthern analysis, hybridization was performed with a solution [6x SSC , $5 \times$ Denhardt's solution, $0.5 \%$ SDS, $0.1 \mathrm{mg} / \mathrm{ml}$ of denatured salmon sperm DNA, $50 \%$ formamide] at $42^{\circ} \mathrm{C}$ containing a probe, and washing was performed under stringent conditions $(0.1 \times \mathrm{SSC}, 0.1 \% \mathrm{SDS})$ at $65^{\circ} \mathrm{C}$. DN A sequencing was carried out by Applied Biosystems automated sequencers (model 373A) using dye primers or dye terminators as recommended by the manufacturer.

\section{I solation of the HY 5 gene}

Linkage between the hy 5 phenotype and the inserted T-DN A in the hy5-Ks50 mutant was examined in 11 plants of the T2 generation. Because one of the three T-DNA insertion loci cosegregated with the hy5 locus, we isolated a genomic DNA fragment flanking the T-DNA using the TAIL PCR method (Liu et al. 1995). The PCR reactions were carried out in a Perkin Elmer Cetus thermal cycler (model 9600). We tried several sets of primers specific for the left and right borders of the T-DNA, and a 1.1-kb PCR fragment containing a genomic sequence flanking the left border of the T-DNA was amplified by use of a set of primers: an arbitrary degenerate primer, $5^{\prime}-\mathrm{NTCGA}(\mathrm{G} /$ C)T (A/T)T (G/C)G (A/T)GTT-3' (15-mer); a specific primer for the primary reaction, $5^{\prime}$-CACATCATCTCATTGATGCTTGGT-3' (24-mer); and a specific primer for the secondary reaction, 5'-GTGTTATTAAGTTGTCTAAGCGTC-3' (24-mer). Because the 1.1-kb PCR fragment showed restriction fragment length polymorphism (RFLP) between Ws (4.5 kb) and Ler (12 kb) ecotypes when digested with Pstl, 165 mutants in the $F_{2}$ generation [hy5-1 (Ler) $\times$ Ws wild-type parents] were examined for the RFLP. Because all of them showed the Ler-type band pattern, we proved that the PCR fragment was tightly linked to the HY5 locus. We screened a genomic library prepared from A rabidopsis DNA (Ws wild type) that was partially digested with Sau3AI and ligated into the Lambda DASH II vector (Stratagene), using the 1.1-kb PCR fragment as the probe. Three independent clones were isol ated and subcl oned into the pBluescript II vector (Stratagene). A 0.7-kb genomic fragment including the bZIP region was used for screening a library constructed from poly $(\mathrm{A})^{+}$RNA prepared from light-grown seedlings of Ara- 
bidopsis (Ler). Three independent cDN A clones were isolated and analyzed.

\section{Complementation test}

A 4.5-kb genomic fragment, containing the HY5 gene, was ligated into a binary vector, pARK5mcs (gift from Meiji-Seika, Kaisha, Ltd., Tokyo, Japan), which carries the bial aphos herbicide resistance marker gene for plant selection. The plasmid was introduced into A. tumefaciens strain C58::pGV2260 by el ectroporation using a Gene Pulsar (Bio-Rad). Transformation of hy5-Ks50 was performed by a vacuum transformation procedure (Bechtold et al. 1993). Seeds of T0 plants were harvested and sown on selection agar medium containing $1 \times$ Gamborg's B5 salt mixture, $5 \mathrm{mg} / \mathrm{liter}$ of bialaphos (gift from M eiji-Seika), and 8 grams/liter of agar, adjusted to $\mathrm{pH} 5.7$ with $\mathrm{KOH}$. Seedlings surviving in the sel ection agar medium were transplanted to soil and grown to obtain their seeds.

\section{Sequence analysis of three hy 5 mutants}

Genomic fragments of hy5-Ks50 including ajunction of T-DN A border and the genome were amplified by PCR, and the fragments were ligated into the pBluescript II vector. Total DNA was extracted from plants of hy5-1 and hy5-215, digested with Xhol, and separated by gel el ectrophoresis. Because HY 5 CDN A was included in a 3.4-kb Xhol fragment, minilibraries were constructed by extracting DN A fragments of $\sim 3.4 \mathrm{~kb}$ from the gel and ligating them into the pBluescript II vector. Then the minilibraries were screened with the HY 5 cDNA used as a probe. Sequences of those subcloned hy 5 genes of the mutants were determined.

\section{Immunofluorescence detection in protoplasts}

The glutathione S-transferase (GST)-HY5 fusion protein was purified from Escherichia coli by use of a GST gene fusion system (Pharmacia). Rabbits were immunized with the GST-HY5 fusion protein. Protoplast preparation and immunological de tection of HY 5 protein were made by basically following the procedures of M atsui et al. (1995). We used the enzyme solution containing 1\% cellulase RS (Yakult Pharmaceutical Ind. Co. Ltd., Tokyo, Japan), $0.25 \%$ pectolyase Y 23 (Sei shin Corporation, Tokyo, Japan), $0.4 \mathrm{~m}$ mannitol, and $10 \mathrm{~mm}$ 2-(N-monopholino) ethanesulfonic acid ( $\mathrm{pH}$ 5.7). As the primary antibody, antiGST-HY5 antiserum of a 1:100 dilution was used. As the secondary antibody, Texas Red-conjugated goat antibody against rabbit IgG (Organon Teknika, West Chester, PA) of a concentration of $5 \mu \mathrm{g} / \mathrm{ml}$ was used. Cells were inspected under an Olympus Provia AX70 microscope.

\section{Acknowledgments}

This work was started in 1993 when the authors were at Division 1 of Gene Expression and Regulation, $\mathrm{N}$ ational Institute for Basic Biology, Okazaki 444, Japan. We are grateful to members of our laboratory, especially A. Kawai, for production of transgenic plant lines; and to S. Sawa, T. Wada, T. Ito, S. Ishiguro, H. Ito, and A. Tanaka for technical assistance and helpful discussions on this work. We thank T. Oosumi, Y.-G. Liu, and R. F. Whittier for providing an Agrobacterium strain, information on the in planta transformation procedure, and permission to use the TAIL PCR method before publication; T. Meshi for discussion about bZIP proteins; X.-W. Deng for providing a mutant line and for helpful discussions on photomorphogenesis; J.-C. Hong for information on STF1 genes; and J. Chory and Y. Ko- meda for providing mutant lines. T.O. was the recipient of a fellowship from Research Fellowships of the Japan Society for the Promotion of Science for Young Scientists. This work was supported by a Grant-in-Aid for Scientific Research (A) (no. 08408031) and a Grant-in-Aid for Scientific Research on Priority A reas (no. 06278103) from the Japanese M inistry of Education, Science, Culture, and Sports and by funds from the Joint Studies Program for A dvanced Studies from the Science and T echnol ogy A gency of Japan.

The publication costs of this article were defrayed in part by payment of page charges. This article must therefore be hereby marked "advertisement" in accordance with 18 USC section 1734 solely to indicate this fact.

\section{References}

Aeschbacher, R.A., J.W. Schiefel bein, and P.N. Benfey. 1994. The genetic and molecular basis of root development. Annu. Rev. Plant Physiol. Plant Mol. Biol. 45: 25-45.

A hmad, M. and A.R. Cashmore. 1993. HY4 gene of A. thaliana encodes a protein with characteristics of a blue-light photoreceptor. Nature 366: 162-166.

Ang, L.-H. and X.-W. Deng. 1994. Regulatory hierarchy of photomorphogenic loci: allele-specific and light-dependent interaction between the HY5 and COP1 loci. Plant Cell 6: 613-628.

Arnon, D.I. 1949. Copper enzymes in isolated chloroplasts. Polyphenoloxidase in Beta vulgaris. Plant Physiol. 24: 1-15.

Ausubel, F.M., R. Brent, R.E. Kingston, D.D. Moore, J.G. Seidman, J.A. Smith, and K. Struhl. 1987. Current protocols in molecular biology. Greene/Wiley, N ew York, NY.

Batschauer, A., P.M. Gilmartin, F. N agy, and E. Schäfer. 1994. The molecular biology of photoregulated genes. In Photomorphogenesis in plants, 2nd ed. (ed R. E. Kendrick and G. H. M. Kronenberg), pp. 559-599. Kluwer Academic Publishers, Dordrecht, $\mathrm{N}$ etherlands.

Bechtold, N., J. Ellis, and G. Pelletier. 1993. In planta Agrobacterium mediated gene transfer by infiltration of adult Arabidopsis thaliana plants. C.R. Acad. Sci. Ser. III Sci. Vi. 316: 1194-1199.

Bennett, M.J., A. Marchant, H.G. Green, S.T. May, S.P. Ward, P.A. Millner, A.R. Walker, B. Schulz, and K.A. Feldmann. 1996. A rabidopsis AU X1 gene: A permease-like regulator of root gravitropism. Science 273: 948-950.

Boerjan, W., M.-T. Cervera, M. Delarue, T. Beeckman, W. Dewitte, C. Bellini, M. Caboche, H. Van Onckelen, M. Van M ontagu, and D. Inzé. 1995. superroot, a recessive mutation in Arabidopsis, confers auxin overproduction. Plant Cell 7: 1405-1419.

Celenza, J.L., Jr., P.L. Grisafi, and G.R. Fink. 1995. A pathway for lateral root formation in Arabidopsis thaliana. Genes \& Dev. 9: 2131-2142.

Chang, S.S., S.K. Park, B.J. Kim, B.J. Kang, D.U. Kim, and H.G. $\mathrm{N}$ am. 1994. Stable genetic transformation of Arabidopsis thaliana by Agrobacterium inoculation in planta. Plant J. 5: 551-558.

Chory, J. 1992. A genetic model for light-regulated seedling development in Arabidopsis. Development 115: 337-354.

Chory, J. 1993. Out of darkness: Mutants reveal pathways controlling light-regulated development in plants. Trends Genet. 9: 167-172.

Chory, J. and C.A. Peto. 1990. Mutations in the DET1 gene affect cell-type-specific expression of light-regulated genes and chloroplast development in Arabidopsis. Proc. Natl. Acad. Sci. 87: 8776-8780. 
Chory, J., C.A. Peto, M. Ashbaugh, R. Saganich, L. Pratt, and F. Ausubel. 1989a. Different roles for phytochrome in etiolated and green plants deduced from characterization of A rabidopsis thaliana mutants. Plant Cell 1: 867-880.

Chory, J., C.A. Peto, R. Feinbaum, L. Pratt, and F. Ausubel. 1989b. A rabidopsis thaliana mutant that devel ops as a lightgrown plant in the absence of light. Cell 58: 991-999.

Cress, W.D. and S.J. Triezenberg. 1991. Critical structural elements of the VP16 transcriptional activation domain. Science 251: 87-90.

Darwin, C. 1882. The power of movement in plants. John M urray, London, UK.

Deng, X.-W. 1994. Fresh view of light signal transduction in plants. Cell 76: 423-426.

Deng, X.-W. and P.H. Quail. 1992. Genetic and phenotypic characterization of copl mutants of Arabidopsis thaliana. Plant J. 2: 83-95.

Deng, X.-W., T. Casper, and P.H. Quail. 1991. CO P1, a regulatory locus involved in the light-controlled development and gene expression in Arabidopsis. Genes \& Dev. 5: 1172-1182.

Deng, X.-W., M. Matsui, N. Wei, D. Wagner, A. M. Chu, K. A. Feldmann, and P. H. Quail. 1992. COP1, an Arabidopsis regulatory gene, encodes a protein with both a zinc-binding motif and a $G \beta$ homologous domain. Cell 71: 791-801.

Di Laurenzio, L., J. Wysocka-Diller, J. Malamy, L. Pysh, Y. HeIariutta, G. Freshour, M.G. Hahn, K.A. Feldmann, and P.N Benfey. 1996. The SCARECROW gene regulates an asymmetric cell division that is essential for generating the radial organization of the Arabidopsis root. Cell 86: 423-433.

Dolan, L. and K. Roberts. 1995. Plant devel opment: Pulled up by the roots. Curr. O pin. Genet. Dev. 5: 432-438.

Dolan, L., K. Janmaat, V. Willemsen, P. Linstead, S. Poethig, K. Roberts, and B. Scheres. 1993. Cellular organisation of the Arabidopsis thaliana root. Development 119: 71-84.

Ellenberger, T.E., C.J. Brandl, K. Struhl, and S.C. Harrison. 1992. The GCN 4 basic region leucinezipper binds DNA as a dimer of uninterrupted $\alpha$ helices: crystal structure of the proteinDNA complex. Cell 71: 1223-1237.

Feldman, L.J. 1984. Regulation of root development. Annu. Rev. Plant Physiol. 35: 223-242.

Foster, R., T. Izawa, and N .-H. Chua. 1994. Plant bZIP proteins gather at ACGT elements. FASEB J. 8: 192-200.

Guiltinan, M.J., W.R.J. Marcotte, and R.S. Quatrano. 1990. A plant leucine zipper protein that recognizes an abcisic acid response el ement. Science 250: 267-271.

Hartings, H., M. Maddaloni, N. Lazzaroni, N. Di Fonzo, M. M otto, F. Salamini, and R. Thompson. 1989. The $O 2$ gene which regulates zein deposition in maize endosperm encodes a protein with structural homologies to transcriptional activators. EMBO J. 8: 2795-2801.

Hobbie, L. and M. Estelle. 1995. The axr4 auxin-resistant mutants of Arabidopsis thaliana define a gene important for root gravitropism and lateral root initiation. Plant J. 7: 211220.

Juniper, B.E. 1976. Geotropism. Annu. Rev. Plant Physiol. 27: 385-406.

Katagiri, F., E. Lam, and N .-H. Chua. 1989. Two tobacco DN Abinding proteins with homology to the nuclear factor CREB. Nature 340: 727-730.

Kelly, M.O. and K.J. Bradford. 1986. Insensitivity of the Diageotropica tomato mutant to auxin. Plant Physiol. 82: 713-717.

Klimczak, L.J., U. Schindler, and A.R. Cashmore. 1992. DNA binding activity of the Arabidopsis G-box binding factor GBF1 is stimulated by phosphorylation by Casein Kinase II from broccoli. Plant Cell 4: 87-98.

Koornneef, M., E. Rolff, and C.J.P. Spruit. 1980. Genetic control of light-inhibited hypocotyl elongation in Arabidopsis thaliana (L.) Heynh. Z. Pflanzenphysiol. 100: 147-160.

Kopczak, S.D., N.A. Haas, P.J. Hussey, C.D. Silflow, and D.P. Snustad. 1992. The small genome of A rabi dopsis contains at least six expressed $\alpha$-tubulin genes. Plant Cell 4: 539-547.

Laskowski, M.J., M.E. Williams, H.C. N usbaum, and I.M. Sussex. 1995. Formation of lateral root meristems is a two-stage process. Development 121: 3303-3310.

Leyser, H.M.O., C.A. Lincoln, C. Timpte, D. Lammer, J. Turner, and M. Estelle. 1993. Arabidopsis auxin-resistance gene AXR1 encodes a protein related to ubiquitin-activating enzyme E1. Nature 364: 161-164.

Lin, C., D.E. Robertson, M. A hmad, A.A. Rai bekas, M.S. Jorns, P.L. Dutton, and A.R. Cashmore. 1995. Association of flavin adenin dinucl eotide with the A rabidopsis blue light receptor CRY1. Science 269: 968-970.

Liu, Y.-G., N. Mitsukawa, T. Oosumi, and R.F. Whittier. 1995. Efficient isolation and mapping of Arabidopsis thaliana $\mathrm{T}$ DNA insert junctions by thermal asymmetric interlaced PCR. Plant J. 8: 457-463.

Liu, Z.-B., T. Ulmasov, X. Shi, G. Hagen, and T.J. Guilfoyle. 1994. Soybean GH3 promoter contains multiple auxin-inducible elements. Plant Cell 6: 645-675.

Malamy, J.E. and P.N. Benfey. 1997. Organization and cell differentiation in lateral roots of Arabidopsis thaliana. Development 124: 33-44.

Matsui, M., C.D. Stoop, A.G. von Arnim, N. Wei, and X.-W. Deng. 1995. Arabidopsis COP1 protein specifically interacts in vitro with a cytoskeleton-associated protein, CIP1. Proc. Natl. Acad. Sci. 92: 4239-4243.

McN ellis, T.W. and X.-W. Deng. 1995. Light control of seedling morphogenetic pattern. Plant Cell 7: 1749-1761.

McN ellis, T.W., A.G. von Arnim, T. Araki, Y. Komeda, S. Miséra, and X.-W. Deng. 1994. Genetic and molecular analysis of an allelic series of copl mutants suggests functional roles for the multiple protein domains. Plant Cell 6: 487-500.

Menkens, A.E., U. Schindler, and A.R. Cashmore. 1995. The G-box: A ubiquitous regulatory DNA element in plants bound by the GBF family of bZIP proteins. Trends Biochem. Sci. 20: 506-510.

Okada, K. and Y. Shimura. 1990. Reversible root tip rotation in A rabidopsis seedlings induced by obstacle-touching stimuIus. Science 250: 274-276.

- - 1992a. Aspects of recent developments in mutational studies of plant signaling pathways. Cell 70: 369-372.

- - - 1992b. Mutational analysis of root gravitropism and phototropism of Arabidopsis thaliana seedlings. Aust. J. Plant Physiol. 19: 439-448.

- - - 1994. M odulation of root growth by physical stimuli. In Arabidopsis (ed E.M. M eyerowitz and C.R. Somerville), pp. 665-684. Cold Spring Harbor Laboratory Press, Cold Spring Harbor, NY.

Padgett, R.A., P.J. Grabowski, M.M. Konarska, S. Seiler, and P.A. Sharp. 1986. Splicing of messenger RNA precursors. Annu. Rev. Biochem. 55: 1119-1150.

Parks, B.M. and P.H. Quail. 1991. Phytochrome-deficient hy1 and hy2 long hypocotyl mutants of A rabidopsis are defective in phytochrome chromophore biosynthesis. Plant Cell 3: 1177-1186.

Pearson, R.B. and B.E. Kemp. 1991. Protein phosphorylation site sequences and consensus specificity motifs: Tabulations. Methods Enzymol. 200: 62-81.

Pepper, A., T. Delaney, T. Washburn, D. Poole, and J. Chory. 1994. DET 1, a negative regulator of light-mediated devel opment and gene expression in Arabidopsis, encodes a novel nuclear-localized protein. Cell 78: 109-116. 
Reed, J.W., P. N agpal, D.S. Poole, M. Furuya, and J. Chory. 1993. Mutations in the gene for the red/far-red light receptor phytochrome B alter cell elongation and physiological responses throughout A rabi dopsis devel opment. Plant Cell 5: 147-157.

Sambrook, J., E.F. Fritsch, and T. Maniatis. 1989. Molecular cloning: A laboratory manual, 2nd ed. Cold Spring Harbor Laboratory, Cold Spring Harbor, NY.

Schindler, U., A.E. M enkens, H. Beckmann, J.R. Ecker, and A.R. Cashmore. 1992a. Heterodimerization between light-regulated and ubiquitoulsy expressed A rabidopsis GBF bZIP proteins. EMBO J. 11: 1261-1273.

Schindler, U., W. Terzaghi, H. Beckmann, T. Kadesch, and A.R. Cashmore. 1992b. DNA binding site preferences and transcriptional activation properties of the Arabidopsis transcription factor GBF1. EMBO J. 11: 1275-1289.

Schmidt, R.J., F.A. Burr, M.J. Aukerman, and B. Burr. 1990. $M$ aize regulatory gene opaque-2 encodes a protein with a "leucine-zipper" motif that binds to zein DNA. Proc. Nat. Acad. Sci. 87: 46-50.

Simmons, C., D. Söll, and F. Migliaccio. 1995. Circumnutation and gravitropism cause root waving in A rabidopsis thaliana. J. Exp. Bot. 46: 143-150.

Suckow, M., B. von Wilcken-Bergmann, and B. Müller-Hill. 1993. Identification of three residues in the basic regions of the bZIP proteins GCN 4, C/EBP and TAF-1 that are involved in specific DNA binding. EMBO J. 12: 1193-1200.

Tabata, T., H. Takase, S. Takayama, K. Mikami, A. N akatsuka, H. Kawata, T. N akayama, and M. Iwabuchi. 1989. A protein that binds to a cis-acting el ement of wheat histone genes has a leucine zipper motif. Science 245: 965-967.

Tabata, T., T. N akayama, K. Mikami, and M. Iwabuchi. 1991. HBP-1a and HBP-1b: Leucine zipper-type transcription factors of wheat. EMBO J. 10: 1459-1467.

von Arnim, A.G. and X.-W. Deng. 1994. Light inactivation of Arabidopsis photomorphogenic repressor COP1 involves a cell-specific regulation of its nucleocytoplasmic partitioning. Cell 79: 1035-1045.

Wareing, P.F. and I.D.J. Phillips. 1981. Growth and differentiation in plants, 3rd ed. Pergamon Press, Oxford, UK.

Wilkins, M.B. 1966. Geotropism. Annu. Rev. Plant Physiol. 17: 379-408.

Zobel, R.W. 1974. Control of morphogenesis in the ethylenerequiring tomato mutant, diageotropica. Can. J. Bot. 52: 735-741. 


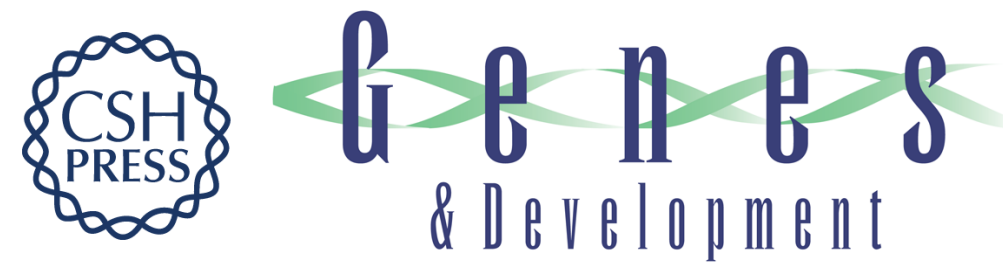

\section{The Arabidopsis HY5 gene encodes a bZIP protein that regulates stimulus-induced development of root and hypocotyl}

Tokitaka Oyama, Yoshiro Shimura and Kiyotaka Okada

Genes Dev. 1997, 11:

Access the most recent version at doi:10.1101/gad.11.22.2983

References This article cites 60 articles, 27 of which can be accessed free at:

http://genesdev.cshlp.org/content/11/22/2983.full.html\#ref-list-1

License

Email Alerting Receive free email alerts when new articles cite this article - sign up in the box at the top Service right corner of the article or click here.

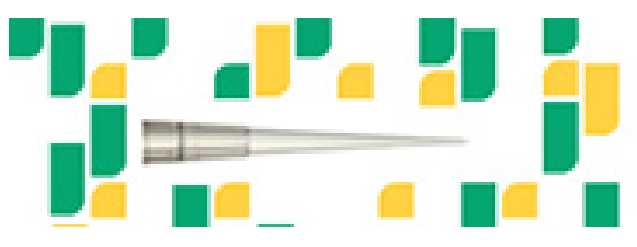

Focused on your science. 